\title{
A STUDY ON ALBANIAN STUDENTS' PERCEPTIONS OF THE ESP COURSES CONTRIBUTION TO THEIR ENGINEERING/ARCHITECTURE KNOWLEDGE ACQUISITION AND COMMUNICATION COMPETENCE
}

\author{
Mirela Alhasani \\ Epoka University, Tirana, Albania
}

\begin{abstract}
Currently, soft skills mainly communication skills of engineering/architecture graduates have been considered as essential as their hard skills for the $21^{\text {st }}$ century competitive global market. Given the cramped curricula of engineering/architecture programs, the research examines the beneficial impact that ESP undergraduate courses have on the tailored communication of engineering/architecture students at a case study analysis - EPOKA University in Tirana, Albania. In order to obtain feedback and unbiased perceptions on the tangible improvement in advanced English communication skills and disciplinary content knowledge acquisition, a questionnaire survey was conducted with the undergraduate students of EPOKA University at the Faculty of Architecture and Engineering upon successful completion of the two mandatory ESP courses at undergraduate level. A mixed method was utilized to collect the statistical data from questionnaires and the semi-structured interviews with students of engineering majors and architecture at the Faculty of Architecture and Engineering of EPOKA University who took English for Academic Purposes and Engineering English during 2018-2020 academic years. Research findings revealed the growing appreciation and high interest that students are placing into ESP courses as significant contributors to knowledge acquisition and soft skill betterment alongside the classic disciplinary courses of their disciplines.
\end{abstract}

Key words: engineering/architecture major, ESP courses, needs analysis, students survey

\section{INTRODUCTION}

This research presents a case study investigation obtaining students' feedback on the role of English courses to their professional development and academic accomplishment at EPOKA university, an international English-speaking university in Tirana the capital of Albania. It is a student -centered research to grasp the linguistic needs and perceptions of students through a Needs Analysis survey. Participants in the survey study were students who successfully completed the two obligatory, English for Academic Purposes taken first semester and English for Engineering taught at the second semester of first year undergraduate studies at the Faculty of Architecture and Engineering at EPOKA University in Albania. Thus, the study follows the most contemporary pedagogical and

Submitted October $1^{\text {st }}, 2020$, accepted for publication November $10^{\text {th }}, 2020$

Corresponding author: Mirela Alhasani. Computer Engineering Department, Epoka University, Tirana, Albania

|E-mail: malhasani@epoka.edu.al 
curriculum design approach of putting the courses to the tangible needs of the students rather than students fitting into a given mandatory course by the teacher. Nunan points out that 'in a learner-centered classroom decision about what will be taught, how it will be taught, when it will be taught, and how it will be assessed will be made with references to the learner' (Nunnan, 2013). This study pursues the contemporary curriculum design approach of curriculum courses which considers students' evaluation of their needs and learning inputs, goals and objectives set up by a university class.

Brown argues that needs analysis is 'the systematic collection of, and analysis of all subjective and objective information necessary to define and validate defensible curriculum purposes that satisfy the language learning' requirements of students within the context of particular institutions that influence the learning and the teaching situation' (Brown, 1995). Moreover, reputable proponents of English for Specific Purposes such as Hutchinson and Waters accentuate the importance of a needs analysis in order to receive the genuine attitudes of leaners as an advantageous point of the ESP versus the General English where in ESP the learner is aware of the existence of specific needs for language (Tom Hutchinson \& Alan Waters, 1987). The importance of needs analysis in course design and syllabus compilation has been early emphasized by regional researchers like Stojkovic and Zickovic while shifting from GE to ESP by gathering the necessary details to prepare ESP courses in technology to boost the technical English and upgrade the engineering knowledge of adult learners (Nadezda Stojkovic \& Sladana Zivkovic, 2013).

This academic endeavor represents a novel priority in Albanian academia to establish the dignified status of English curriculum at a faculty of applied sciences where there is no tradition of research on the impact of ESP courses into the qualification of future engineers/architects in the global market. Likewise, elsewhere, English for Specific Purposes has not gained a status of high recognition vis a vis other scientific majors in regional and international academic community. ESP proponents are determined to reveal the deserved professional and academic values of ESP courses even versus General English Learning supremacy at all three cycles of education (Stojkovic, 2019).

\section{METHOD}

A mixed qualitative and quantitative research method has been adopted to reach original findings from this research. Original and unbiased data were collected through a questionnaire delivered to undergraduate students who had already successfully completed the two ESP courses offered at undergraduate level at the Faculty of Architecture and Engineering of EPOKA university during academic years 2018-2020.

\subsection{Participants}

A google form questionnaire accessible at https://forms.gle/pWuR2fnAGqpX3fis5 asked students to evaluate the effectiveness of the ESP courses to their soft skill improvements. It was addressed to 300 students enrolled in such ESP courses respectively in two consequent academic years for the first time at the faculty during 2017-2018 and 2018-2019; the author of this research is the ESP lecturer at EPOKA University carrying out the survey in person. Since the google form questionnaires and the survey as such were conducted during the pandemic months of Corvid -19, out of 300, 231 students accepted to participate in the survey. These students were mainly from Computer engineering department (150) as the 
largest one of the faculty, the second in number were the students of Architecture (58) to be followed by Civil engineering and Electronics programs with the least number of enrolled freshmen at faculty level. Students were all freshmen of age 18-20 and therefore, to have their independent feedback on the impact of language courses to their academic and professional growth was a novelty at an applied science faculty where students devote many years of advanced preparation to hard sciences like mathematics and physics; apparently the foreign language course program had never been given any attribute for further career prospects.

\subsection{Research instruments}

Data were gathered through a questionnaire prepared in google form and delivered only to students of EPOKA email domain enrolled in computer engineering, civil engineering, electronics and architecture program. The questionnaire was prepared in Likert Scale from the least to the most important or significant value, combined with some close YES or NO questions; some semi-structured interview questions since the author in pandemic conditions could not interview students in person but intertwined the face to face questions at point 7 of this online questionnaire.

\section{DISCUSSION OF FINDINGS}

Question 1.

Were you satisfied to switch from general ELT to English for Specific Courses at Epoka University? 231 responses

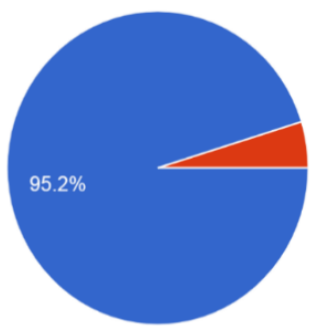

Yes

No

The first question was deliberately put to have a precise reaction of students themselves whether they had realized the need to move from General English to tailored courses of Advanced English. A strong confirmation of $95.2 \%$, i.e. 220 students out of 231 respondents were satisfied to be offered such a new type of English course versus a negative of 11 students. This indicator is significant to demonstrate the appreciated status of ESP by university learners. As a typical ESP approach, the major responsibility of the ESP lecturer is to diagnose the needs, the strengths and weaknesses of their leaners. Moreover, Celik points out that learners' awareness of the need in language is the starting point of a researcher (Celik, 2017). Therefore, the starting point of the research is a strong positive reply of students by having self-reflected on the necessity to switch from the General English mainstream of high school to specific professional content driven courses at university studies. This ESP needs analysis approach will also serve as a good practice to other curricula courses of specific discipline in terms of improving their efficacy and achieving the learning outcomes and fulfilling the objectives set by the instructor. 
Rate from the lowest to the highest scale the usefulness of the followings items in your ESP class 1 to 5.

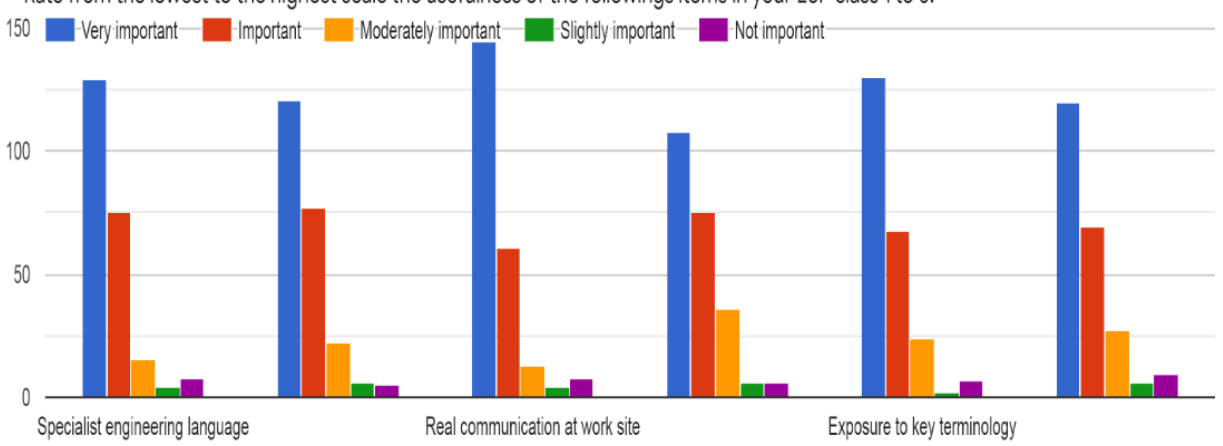

Regarding the second question put in Likert Scale with seven mini sections to be ranked in order of importance by students. The first variable to be checked for question 2 was the usefulness of ESP courses to specialist engineering language with 129 students scoring it very important; 75 students considered it important; 15 students scored moderately important; 4 students considered slightly important; and only 8 students out of total of 231 marked the ESP courses at EPOKA as not important.

\begin{tabular}{|l|c|c|c|c|c|}
\hline Sub variable & $\begin{array}{c}\text { Very } \\
\text { important }\end{array}$ & Important & $\begin{array}{c}\text { Moderately } \\
\text { Important }\end{array}$ & $\begin{array}{c}\text { Slightly } \\
\text { Important }\end{array}$ & $\begin{array}{c}\text { Not } \\
\text { Important }\end{array}$ \\
\hline $\begin{array}{l}\text { Specialist engineering } \\
\text { Language }\end{array}$ & 129 students & 75 students & 15 students & 4 students & 8 students \\
\hline Authentic Communication & 121 & 77 & 22 & 6 & 5 \\
\hline $\begin{array}{l}\text { Real Communication } \\
\text { at Work Site }\end{array}$ & 145 & 61 & 13 & 4 & 8 \\
\hline $\begin{array}{l}\text { Soft skills improvements } \\
\text { in pair tasks }\end{array}$ & 108 & 75 & 36 & 6 & 6 \\
\hline $\begin{array}{l}\text { Exposure to } \\
\text { Key terminology }\end{array}$ & 130 & 68 & 24 & 2 & 7 \\
\hline $\begin{array}{l}\text { Exercises/tasks to problem- } \\
\text { solving scenarios }\end{array}$ & 120 & 69 & 27 & 6 & 9 \\
\hline
\end{tabular}

Moreover, the table with the statistics shows that 145 students scored as very important the contribution of ESP course to their real communication at Work site; 108 responded positively to its contribution to soft skills improvements through pair tasks; 130 scored maximum to very important support in exposing them to key terminology along with 120 scoring maximum to problem-solving skills improved by task-based exercises. This confirmative feedback of students themselves comprises a convincing evidence of the valuable contribution of the ESP courses to building social competence at work and university. Soft skills and solving problem capabilities are issues that have been largely explored and investigated by language curriculum designer such as Stefanowicz-Kocol \& Pociask arguing that social competences belong to transversal skills which can be practiced in language courses (AnnaStefanowics-Kocol \&Monika Pociask, 2017). 
How much specialist knowledge vocabulary did you have in your field of study before the ESP course (Academic reading and writing level; Engineering English Level II)? 231 responses

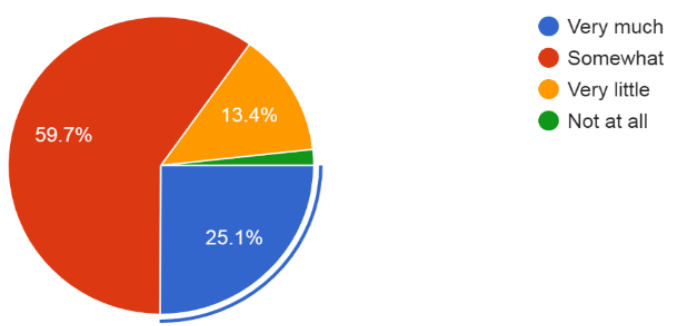

Question three makes a more specific point on the knowledge prior to taking ESP courses in order to check the beneficial inputs and outputs of the EAP and Engineering English courses. It was found that only $25.1 \%$ claimed of having had very much knowledge in technical vocabulary of advanced English, whereas a majority of $59.7 \%$ admitted that they had somewhat knowledge and thus the courses were of great help to further lexical enrichment in the major of study.

\begin{tabular}{|l|c|r|}
\hline Very much & $25 \%$ & 58 students \\
\hline Somewhat & $59.7 \%$ & 138 students \\
\hline Very little & $13.4 \%$ & 31 students \\
\hline Not at all & $1.7 \%$ & 4 students \\
\hline
\end{tabular}

Moreover, this feedback highlights the need to use authentic materials with key terminology to the field of study. The fact that only $25 \%$ out of total confirmed of having very much professional linguistic vocabulary, reveals the necessity to expose them to professional terminology through ESP course materials as a bridge to further understanding their disciplinary content courses. Authentic materials originating from students' self-perception of vocabulary needs is another major attribute of ESP teaching program and, of the ESP teacher by selecting the right authentic materials in advance as safe tool box (Vesna Stankovic \& Dusica Milosavljevic, 2017).

Did you have an international experience (learning/work and travel) to test your English

Communication as a non-native speaker?

231 responses

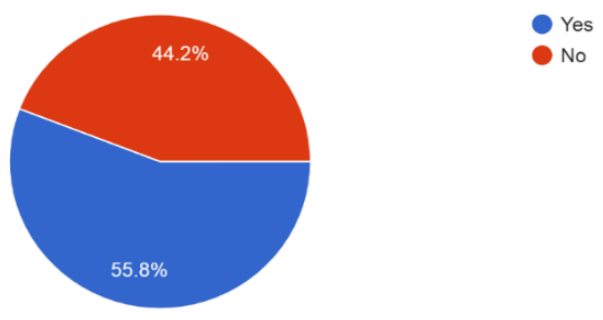

This question aims at gaining direct information from students who have participated either in Work and Travel program in the USA or Erasmus + Students mobility programs in English language. These two programs are coordinated and endorsed by EPOKA university. 
It goes without doubts that English has become the lingua franca of internationalization among educational institutions but, precisely this attribute goes to ESP due to its specific features for specific disciplinary programs. Out of 231 total, 102 students making $44.2 \%$ had already had an international experience using English as non-native English speaker. Meanwhile, 129 students had not yet had such an international practice to test their communicative competence in English abroad.

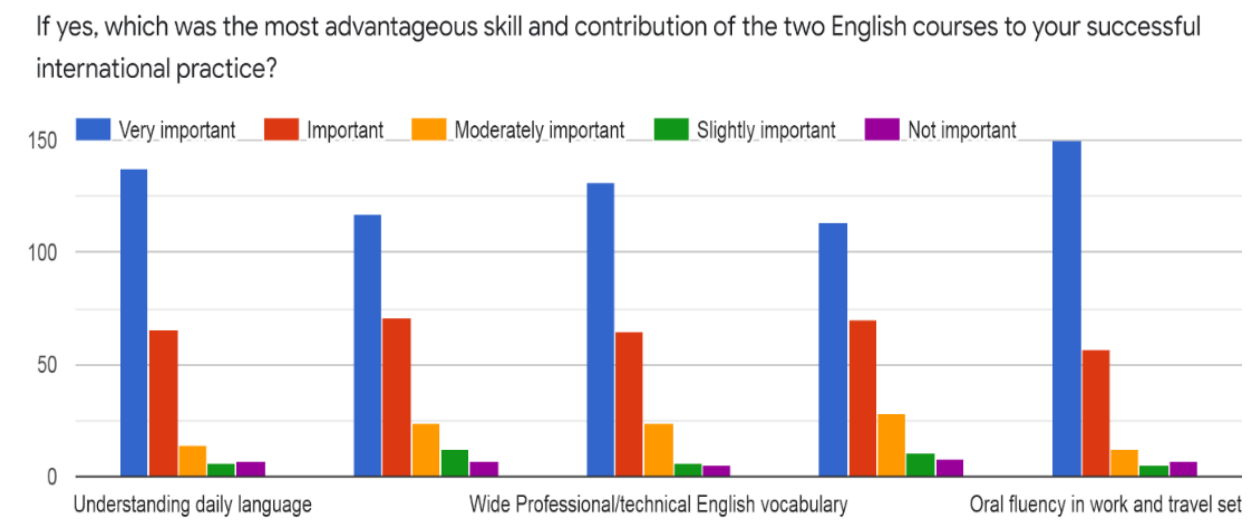

\begin{tabular}{|l|c|c|c|c|c|}
\hline $\begin{array}{l}\text { ESP Courses } \\
\text { contribution }\end{array}$ & $\begin{array}{c}\text { Very } \\
\text { Important }\end{array}$ & Important & $\begin{array}{c}\text { Moderately } \\
\text { Important }\end{array}$ & $\begin{array}{c}\text { Slightly } \\
\text { important }\end{array}$ & $\begin{array}{c}\text { Not } \\
\text { important }\end{array}$ \\
\hline $\begin{array}{l}\text { Understanding Daily } \\
\text { Language }\end{array}$ & 138 & 66 & 14 & 6 & 7 \\
\hline $\begin{array}{l}\text { Cultural/Social } \\
\text { Integration in Foreign } \\
\text { Society }\end{array}$ & 117 & 71 & 24 & 12 & 7 \\
\hline $\begin{array}{l}\text { Wide professional } \\
\text { Technical English }\end{array}$ & 131 & 65 & 24 & 6 & 5 \\
\hline $\begin{array}{l}\text { Written } \\
\text { Communication }\end{array}$ & 114 & 70 & 28 & 11 & 8 \\
\hline $\begin{array}{l}\text { Oral fluency in Work } \\
\text { and Travel Setting }\end{array}$ & 150 & 57 & 12 & 5 & 7 \\
\hline
\end{tabular}

This set of semi-structured questions comply with the contemporary role and responsibility of an ESP lecturer who, according to Chmelikova and Hurajova must possess "solid English language competence, adequate knowledge of the related HEI disciplines, awareness of specific needs of stakeholders in question as well as experience with cultural issues of the current international environment" (Gabriela Chmelikova \& Ludmilla Hurajova, 2019). The driving power of ESP for further internationalization in education and science has been acknowledged and endorsed by European institutions and EU agencies such as the Visegrad + Funds Agency by supporting financially ESP regional project. For instance, the latest project in the Visegrad+Scheme CLIL-HET (CLIL-Higher Education Teacher) increases interdisciplinary cooperation at regional level though ESP didactic training and practice dissemination. Therefore, this question reflects the added value of ESP class to successful international working and/or educational experience. It is a very 
enthusiastic finding that 150 out of 231 in total responded with the highest score to having achieved spoken fluency at work and education through ESP class. In addition, 138 out of 231 confirmed the wide technical vocabulary of the class as having been very important to their successful international experience.

Question 6: Potential of ESP Courses- Rate the English skills that the ESP courses improved to your general English potentials

\begin{tabular}{|l|c|c|c|c|c|}
\hline Potential of ESP Courses & $\begin{array}{c}\text { Very } \\
\text { important }\end{array}$ & Important & $\begin{array}{c}\text { Moderately } \\
\text { Important }\end{array}$ & $\begin{array}{c}\text { Slightly } \\
\text { important }\end{array}$ & $\begin{array}{c}\text { Not } \\
\text { important }\end{array}$ \\
\hline $\begin{array}{l}\text { Providing knowledge content } \\
\text { in Engineering }\end{array}$ & 126 & 76 & 13 & 8 & 8 \\
\hline $\begin{array}{l}\text { Listening to } \\
\text { authentic situations }\end{array}$ & 111 & 80 & 24 & 11 & 5 \\
\hline $\begin{array}{l}\text { Writing technical and academic } \\
\text { genres }\end{array}$ & 133 & 66 & 20 & 8 & 4 \\
\hline $\begin{array}{l}\text { Familiarizing with different } \\
\text { rhetorical functions of scientific } \\
\text { English }\end{array}$ & 127 & 66 & 21 & 13 & 4 \\
\hline $\begin{array}{l}\text { Acquiring interpretative and } \\
\text { study skills including library } \\
\text { and internet reference skills }\end{array}$ & 133 & 63 & 18 & 9 & 8 \\
\hline $\begin{array}{l}\text { Getting trained in organized } \\
\text { academic and professional }\end{array}$ & 139 & 59 & 18 & 10 & 5 \\
\hline $\begin{array}{l}\text { Developing oral competence } \\
\text { and fluency of learners }\end{array}$ & 127 & 74 & 17 & 9 & 4 \\
\hline $\begin{array}{l}\text { Achieving proficiency in the } \\
\text { effective use of language, } \\
\text { in various authentic } \\
\text { career-related situations }\end{array}$ & 152 & 54 & 13 & 6 & 6 \\
\hline
\end{tabular}

This set of sub-structured variables are in line with a detailed needs analysis survey for an ESP course evaluation. It exhibits the high importance students gave to each of these sub variables of ESP potential contributions to their linguistic and professional development. These questions incorporate both the four dimensions of English learning - reading, listening, writing, speaking and, in addition as an ESP course taught to adult learners it depicts specific contribution to social competence and professional development in the future thought tailored Engineering courses. It is very significant finding that 152 students out of 231 pointed as very important contribution of ESP courses to achieving proficiency in the effective use of language, in various authentic career-related situations. Also, 133 participants assessed as very important the role of ESP courses to acquiring interpretative and study skills including library and internet reference skills. 
Did the ESP courses contribute to your development to meet your academic/professional goals likewise other curricula courses?

231 responses

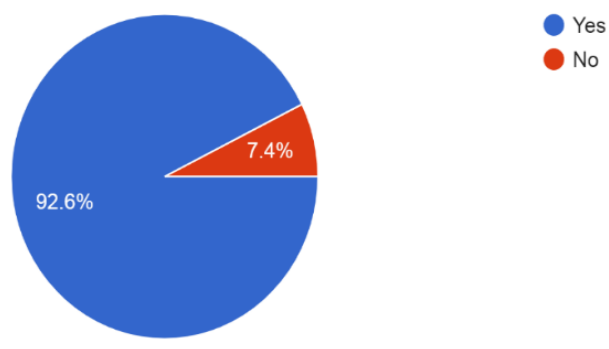

This question was originally placed by the author of this research given the vacuum in research on the status of language courses to overall development of engineering major likewise other already acknowledged courses in the discipline. It is a very motivating and enthusiastic answer of a strong $92.6 \%$ of high appreciation of English courses alongside other disciplinary courses. This final question of the questionnaire shows the validity of the ESP programs expressed by the voice of the students themselves; hence, this represents a most convincing model of a curriculum focused and tailored by the learners to satisfy their linguistic needs in a foreign language with very clear-cut goals of the teaching/learning process. Inclusion of students in preparing the class content, aims and teaching tactics is the most essential distinctive quality of a learner-centered curriculum (Gozuyesil, 2014).

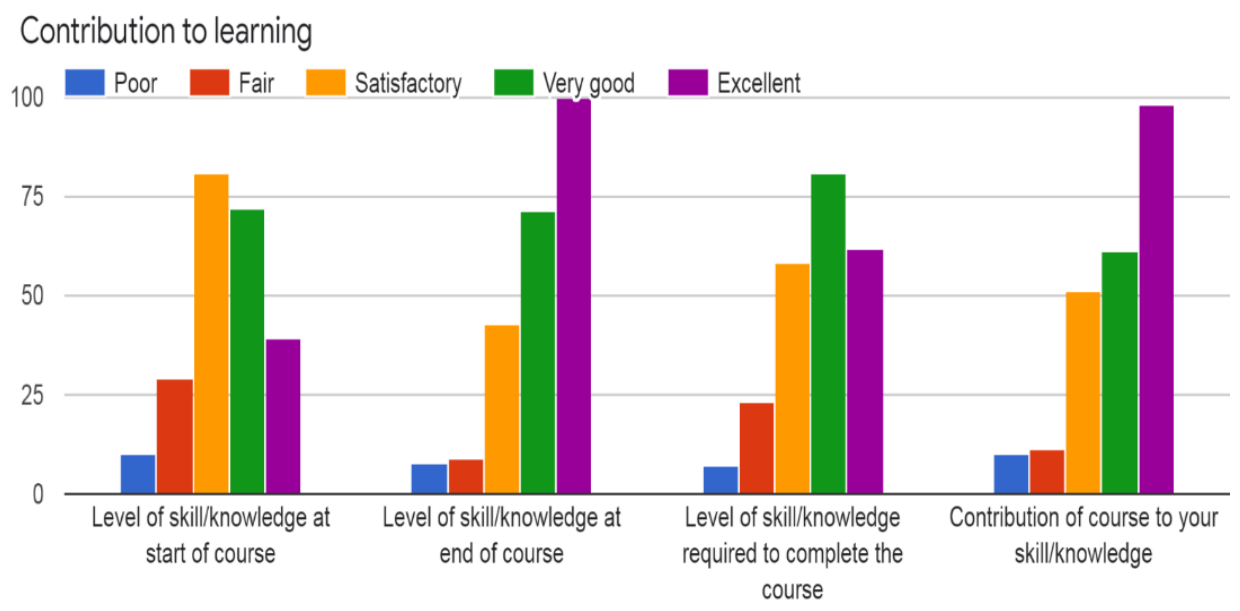

This last question aimed at clearly making a strong point through convincing and concrete evidence about the tangible contribution of the ESP courses to learning by comparing the level at the beginning and end of the courses. At the beginning of enrollment to courses, only 39 students claimed of having excellent knowledge and level skills whereas at the end of the courses 100 students claimed excellent mastery. 


\section{CONCLUSION AND RECOMMENDATION}

This research discussed a case study examination at the Faculty of Engineering and Architecture at EPOKA University in Albania where 231 undergraduate students participated in a questionnaire survey to assess the contribution to their language learning, communicative competence and professional terminology of mandatory ESP courses English for Academic Purposes and Engineering English. The questionnaire was based on Likert scale of significance per questions as well as some closed questions to identify the need for switching from General to Specific English Courses. The questionnaire was designed based on Needs Assessment analysis for a typical ESP class but also some original questions were put to fill in the vacuum of the domestic Albanian context of neglected research in language courses at applied sciences university programs. Predominantly, all variables examined in the survey showed high appreciation and positive feedback from students on the beneficial influence of the ESP courses to their communicative competence and major-tailored knowledge. The findings exhibit positive reaction concerning the necessity to have ESP courses rather than general English courses for further academic and career opportunities. Moreover, those students who had been involved in international experiences were testimonies of the benefits that the engineering vocabulary taught in class had been very useful to them in daily practice and professional engagement. The most essential finding of the study is that students themselves do admit that language courses have a status of importance to them equal to other curricula courses thus, restoring the worthy position of ESP in their squeezed curricula and respecting its attributes. This pilot research with its motivating findings gives us further stimulus to systematically carry on diagnostic measurement of the linguistic needs and course content of ESP university programs in Albania and the region for more effective language competence.

\section{REFERENCES}

Brown, J. D. (1995). The Elements of language curriculum: A systematic approach to program development. Heinle and Heinle.

Celik, H. (2017). Perceived Language Needs of Undergraduate Medical Students Enrolled in a Consecutively Running ESP Course. The Journal of Teaching English for Specific and Academic Purposes, Vol.5(N.2), 209.

Chmelikova, G. \& Hurajova, L. (2019). ESP Teachers in the World of Globalization and Higher Education Internationalization. The Journal of Teaching English for Specific and Academic Purposes, Vol.7(N. 4), 447.

Gozuyesil, E. (2014). An Analysis of Engineering Students' English Language Needs. Procedia- Social and Behavioral Sciences, 4182.

Hutchinson, T. \& Alan Waters. (1987). English For Specific Purposes. Cambridge University Press.

Stefanowics-Kocol, A. , Pociask, M. (2017). Improving Social Competence of Nursing Students in ESP Classes. The Journal of Teaching English for Specific and Academic Purposes, Vol.5 (Nr. 2 ), 259-273

Nunnan, D. (2013). Learner-Centered English Language Education (1st Edition ed.). Routledge, Taylor and Francis Group.

Stojkovic, N. (2019). Possible Reasons Why ESP is Under Recognized in Academia. The Journal of Teaching English for Specific and Academic Purposes, Vol. 7(N. 3 ), 408.

Stojkovic, N. \& Zivkovic, N. (2013). English for Science and Technology Courses at University of Nis, Serbia. The Journal of Teaching English for Specific and Academic Purposes, 8.

Stankovic, V. \& Milosavljevic, D. (2017). Business English for Presentation - Use of the Authentic Materials. The Journal oF Teaching English for Specific and Academic Purposes, Vol. 5(N.2), 347. 